\title{
ADAM10 Gene
}

National Cancer Institute

\section{Source}

National Cancer Institute. ADAM10 Gene. NCI Thesaurus. Code C91858.

This gene plays a role in the regulation of protein cleavage. 